\title{
Kornelija Rakić: A Woman Doctor for Women and Children in Serbia and Bosnia and Herzegovina
}

\author{
Husref Tahirović ${ }^{1}$, Brigitte Fuchs ${ }^{2}$ \\ ${ }^{1}$ Department of Medical Sciences of the Academy of Sciences and Arts of Bosnia and Herzegovina, Sarajevo, Bosnia and \\ Herzegovina ${ }^{2}$ Department of Cultural and Social Anthropology at the University of Vienna, Vienna, Austria
}

Correspondence: husref.tahirovic@untz.ba; brigitte.fuchs@univie.ac.at; Tel.: + 387 61 720-740; Fax.: + 38735303774

Received: 25 January 2021; Accepted: 30 March 2021

\begin{abstract}
This short biography focuses on the life and medical activities of Kornelija Rakić (1879-1952), a Serbian female pioneer of medicine from the then Hungarian province of Vojvodina, who acquired an MD from the University of Budapest in 1905. Rakić came from a humble background, and a Vojvodina Serbian women's organization enabled her to become a physician and pursue her social medicine mission. After a futile attempt to open a private practice as a "woman doctor for women" in Novi Sad in 1906, she successfully applied to the Austro-Hungarian provincial government in Sarajevo for the position of an official female physician in occupied Bosnia. Rakić began her career as an Austro-Hungarian (AH) official female physician in Bihać (1908-1912) and was transferred to Banja Luka in 1912 and to Mostar in 1917-1918. Kornelija Rakić stayed in Mostar after the monarchy collapsed in 1918 and continued to work as a public health officer in the service of the Kingdom of Serbs, Croats and Slovenes, founded in 1918. Subsequently, she served as the head of the "dispensary for mothers and children" at the Public Health Centre in Mostar, founded in 1929, where she practiced until her retirement in 1949. After World War II, Rakić served as Vice President of the Red Cross Society in Mostar. She received numerous awards and medals from the Austro-Hungarian Empire, the Kingdom of Yugoslavia and the Federal People's Republic of Yugoslavia. Kornelija Rakić died in Mostar in 1952 and was buried at the local Orthodox cemetery of Bjelušine. Conclusion. Kornelija Rakić (1879-1952) was the first Serbian female physician in Novi Sad, Vojvodina, and she was employed as an AH official female physician in Bihać (1908-1912), Banja Luka (1912-1917) and Mostar (1917-1918). After World War I, she participated in the establishment and expansion of public health institutions in Mostar and Herzegovina from 1918-1949 against the backdrop of the devastation of the two World Wars.
\end{abstract}

Key Words: (AH) Official Female Doctor - Kornelija Rakić - Novi Sad, Bihać, Banja Luka, Mostar • Serbia • Bosnia and Herzegovina.

\section{Introduction}

In 1911, a short biography of "Dr. Kornelija Rakić" appeared in the first volume of the Serbian women's magazine Žena (1). Žena was edited by Milica Tomić (1859-1944), ${ }^{1}$ an established women's

${ }^{1}$ Milica Tomić (1859-1944) was a writer and Serbian women's activist in Vojvodina. A daughter of the distinguished Serbian politician Svetozar Miletić, she was active for the Serbian women's organization “Dobrotvorna zadruga Srpkinja Novosatkinja" from the 1880s onwards. In 1911, she founded the women's magazine “Žena”, issued 1911-1914 and 1918-1921 [cited 2021 Jan 9]. Available from: https://en.wikipedia.org/ wiki/Svetozar_Mileti\%C4\%87; see also: Gordana Stojaković: activist in Novi Sad who had been active in the Serbian women's movement in Vojvodina since the 1880s. The women's movement was closely linked to the Serbian national movement in the (at the time) Hungarian province $(2,3)$. Tomić herself was the author of the biography, and she explained in the first paragraph that Serbian women's health and wellbeing depended on the practice of female doctors, because many women were too "shy" to consult male doctors. This argumentation corre-

Milica Tomić [cited 2021 Apr 12]. Available from: https:// zenskimuzejns.org.rs/milica-tomic-2/. 
sponds to an argument first used by Czech and Social Democrat women's activists in Austria in the 1890s. These activists used the argument to support a proposal to improve health care for women by introducing public health institutions that employed female doctors. They also argued for women's rights to academic education and particularly medical education. The second paragraph begins to provide information about Kornelija Rakić, who was among the first Serbian women in Vojvodina to acquire an MD at the University of Budapest. ${ }^{2}$ As Tomić points out, Kornelija Rakić had worked as a "woman doctor for women" in Novi Sad before she was "invited" by the Austro-Hungarian (AH) authorities in Bosnia to work as the "first" female doctor in 1908 (1).

In fact, Kornelija Rakić was the seventh female doctor to be employed by the AH provincial government in Sarajevo. Women were admitted to medical studies starting in 1895 in Hungary and 1899 in Austria, and the governor of Bosnia, AH Finance Minister Benjamin de Kallay, created the office of "female health officer" for all districts of the "occupied territory" in 1890 primarily to serve the female Muslim population. The first AH official female doctor in Bosnia, Anna Bayerová, was a well-known Czech feminist who had studied medicine in Switzerland. Bayerová left Bosnia after one year; however, according to Nečas, she was able to shape the office into a social medicine institution "for women and children" during that year, with the governor's consent. Other AH official female doctors included Bohuslava Kecková in Mostar (1892-1911), Teodora Krajewska in Tuzla (18921899) and Sarajevo (1899-1918), Jadwiga Olszewska in Tuzla (1899-1918), Gisela Januszewska in Banja Luka (1899-1912) and Rosa Einhorn in Travnik (1902-1904). These doctors served pre-

${ }^{2}$ The first Serbian woman from Vojvodina (Hungary) who acquired an MD from the University of Zürich was Marija Prita, mariée Vučetić (1866-1954) in 1893; cf. Spasović Ivana B. Dr. Marija Vučetić-Prita, the first woman doctor in Southern Hungary, the second among in the Serbian people [in Serbian]. In: Godišnjak grada Beograda, book 61/62 (2014/2015 [print 2016]), p. 91-106; see also: https://sr.wikipedia.org/sr-el /\%D0\%9C\%D0\%B0\%D1\%80\%D0\%B8\%D1\%98\%D0\%B0_\% D0\%9F\%D1\%80\%D0\%B8\%D1\%82\%D0\%B0. dominantly as general practitioners for women and children, with a focus on Muslim women.

Kornelija Rakić filled the last vacant staff position for an AH official female doctor in Bihać in 1908. Transferred to Mostar in 1918, she stayed in the city for the rest of her life and practiced as a public health professional in the Kingdom of Serbs, Croats and Slovenes (1918-1929), the Kingdom of Yugoslavia (1929-1941), the pro-NS NDH-State (1941-1945) and the Federal People's Republic of Yugoslavia (1945-1963). Rakićs life and medical activities in Bosnia will be the subject of this review, which relies on new sources from Serbian, Hungarian, Yugoslav and Bosnian archives.

\section{Kornelija Rakić's Short Biography}

Though Kornelija Rakić is little known internationally, she is not among the forgotten women pioneers of medicine. Serbian historian Gordana Stojaković (2001) draws on Milica Tomićs portrait (3) in counting Kornelija Rakić as the first female doctor in Novi Sad, among the "famous women" of the city.

Rakić's career as an AH official female doctor in Bihać from 1908-1912, Banja Luka from 1912-1917 and Mostar in 1918 was documented by Czech historian Ctibor Nečas, author of a monograph on the AH institution of female public health officers in Bosnia (4). In the absence of preserved sources other than Rakićs personnel file, Nečas' account of her person and professional activities is poor compared to the administrative and personal records available for other official female doctors. An unpublished research paper by Barbara Martin contextualizes Rakić's activities as an $\mathrm{AH}$ official female doctor by referring to the betterdocumented careers of other AH female officers (Martin, 2017). ${ }^{3}$ In 1918, Kornelija Rakić came to Mostar as an AH official doctor and continued her

${ }^{3}$ We thank Barbara Martin for sharing her research with us; see also Barbara Martin: Zur Tätigkeit von Kornelika Rakić als Amtsärztin in Bosnien-Herzegowina (1908-1918) [cited 2021 Apr 12]. Available from: https://de.scribd. com/document/360574359/Zur-Tatigkeit-von-KornelijaRaki\%C4\%87-als-Amtsarztin-in-Bosnien-Herzegowina. 
social medicine mission in that city for more than 30 years. However, neither Serbian nor BosnianHerzegovinian medical historiography provides a detailed biography of her person (3, 5 -10).

Kornelija Rakić was born on August 19, 1879 in Ruma (11), a town in the region of Syrmia (Srem) in the (at the time) Hungarian province with a predominantly Serbian population. Her parents were Georgij (Đorđe) Rakić, an innkeeper at Ruma, and Ana Crnojević. In 1882, the family moved to Petrovaradin $(12,13)$, an historic Serbian city near Novi Sad; today, this city is part of Vojvodina's capital.

As a young woman from a modest background in Hungary's periphery, Rakić was given the opportunity to obtain higher academic education largely because of the Serbian national movement in Vojvodina. Since 1864, Novi Sad (or Ujvidék in Magyar language) accommodated the "Matica Srpska", a Serbian language cultural-scientific institution founded in 1826 in Pest. In the 1860s, the city became the flourishing centre of the national and cultural "revival" of the Vojvodina Serbs. From the 1870s on, Serbian women's activists advocated for improvements in the social status of Serbian women and the introduction of higher education in Serbian language for girls. Their first success was the establishment of secondary schools for Serbian girls in Novi Sad and Pančevo in 1874, modelled on schools in the principality of Serbia $(14,15)$.

After completing elementary school, Kornelija Rakić attended the girls' higher school in Novi Sad. In school, she was introduced to the ideas of the "Charitable Cooperative of Serbian Women in Novi Sad" (Dobrotvorna zadruga Srpkinja Novosatkinja), which advocated for Serbian women's right to higher academic education (16). Against this background, Kornelija Rakić decided to pursue the medical profession. The only personal document left by Kornelija Rakić is a letter she sent as a student in Budapest in 1901 to her former headmaster, Arkadija Varađanin, which demonstrates that her medical aspirations were supported by the "women's club" even as a pupil (17). Rakić worked as an associate of the women's cooperative monthly magazine Ženski svet (17), and she later worked for the Serbian daily newspaper Zastava (18).
After completing Serbian girls' higher school, Kornelija Rakić had to overcome many obstacles to study medicine. Her school completion exam did not qualify her for university entrance. Women who applied to the Medical Faculty of the University of Budapest in November 1895 were required to submit a "Matura" (general qualification for university entrance) certificate from an Austrian or Hungarian gymnasium. Perhaps mediated by the "women's club", Kornelija Rakić was admitted to the Serbian-Orthodox boys' gymnasium in Novi Sad as a private pupil in $1895(3,5,19)$. She was required to take an exam that included subject matter from the third to eighth grades of the gymnasium, and she passed her Matura exam in 1899 (20).

Funded by a scholarship from the "Charitable Cooperative of Serbian Women in Novi Sad" (Dobrotvorna zadruga Srpkinja Novosatkinja), Kornelija Rakić enrolled at the Medical Faculty of the University of Budapest in 1899 (Picture 1). Unlike at Swiss universities, the number of female students-particularly female students of medicine-remained low (21). Kornelija Rakić pursued her medical studies and was awarded her MD on 9 December 1905 (22) (Picture 2 and Picture 3) by Professor Emil Grósz ${ }^{4}$ after less than six years of study, at the age of 26 years.

Kornelija Rakić completed her medical training by serving three months as a volunteer at the Department of Gynaecology at the university clinic in Budapest (23). Vilmos Tauffer, ${ }^{5}$ the head of this clinic, had introduced modern obstetrics to Hungary. In early 1906, she returned to Novi Sad. In February 1906, an advertisement in Zastava announced that "Dr. Kornelija Rakić" had opened a

${ }^{4}$ Emil Grósz (1865-1941) was a Hungarian ophthalmologist of international reputation. He was professor of ophthalmology at the Faculty of Medicine of the University of Budapest and head of the ophthalmological university clinic from 1905-1936. [cited 2020 Dec 25]. Available from: https:// hu.wikipedia.org/wiki/Gr\%C3\%B3sz_Emil.

${ }^{5}$ Vilmos Tauffer (1851-1934) was a Hungarian obstetrician, gynecologist, and university professor. He was a pioneer in the field in Hungary and reformed Hungarian midwife training. He was among the country's leading obstetricians [cited $2021 \mathrm{Feb} 20]$. Available from: https://www.biographien.ac.at/ oebl/oebl_T/Tauffer_Vilmos_1851_1934.xml. 


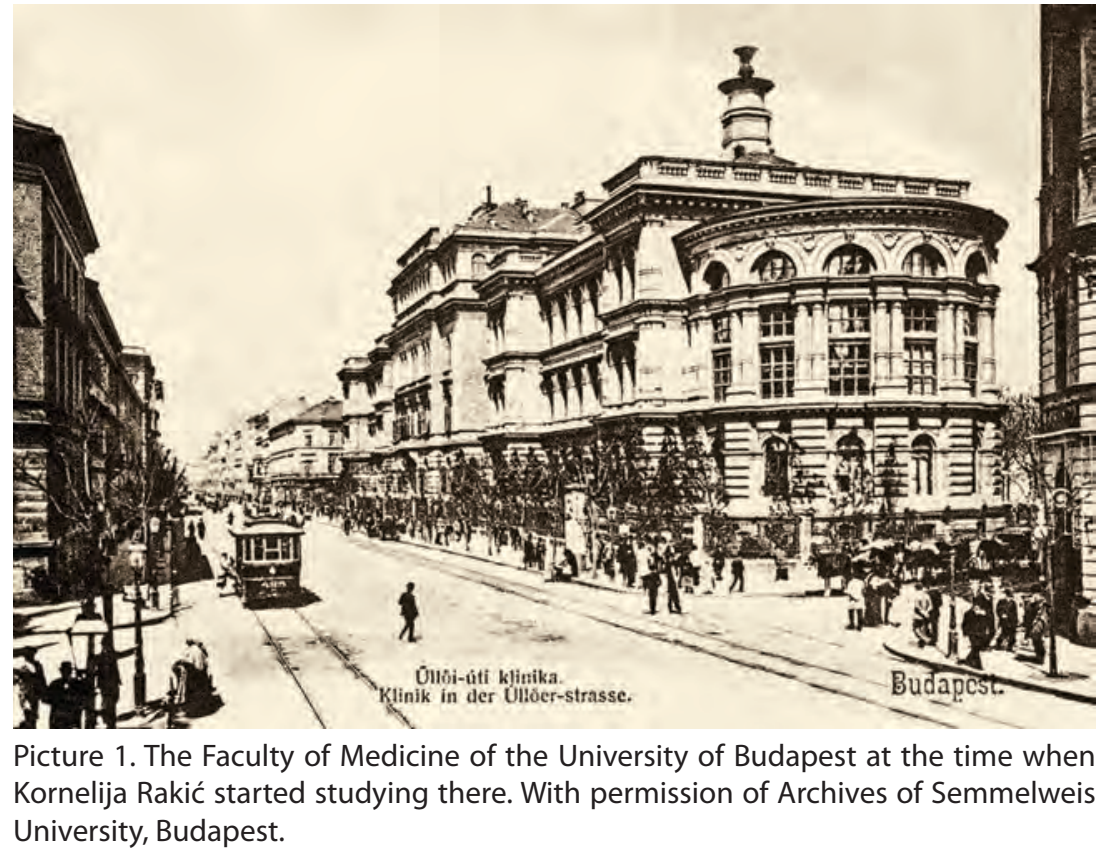

University, Budapest.

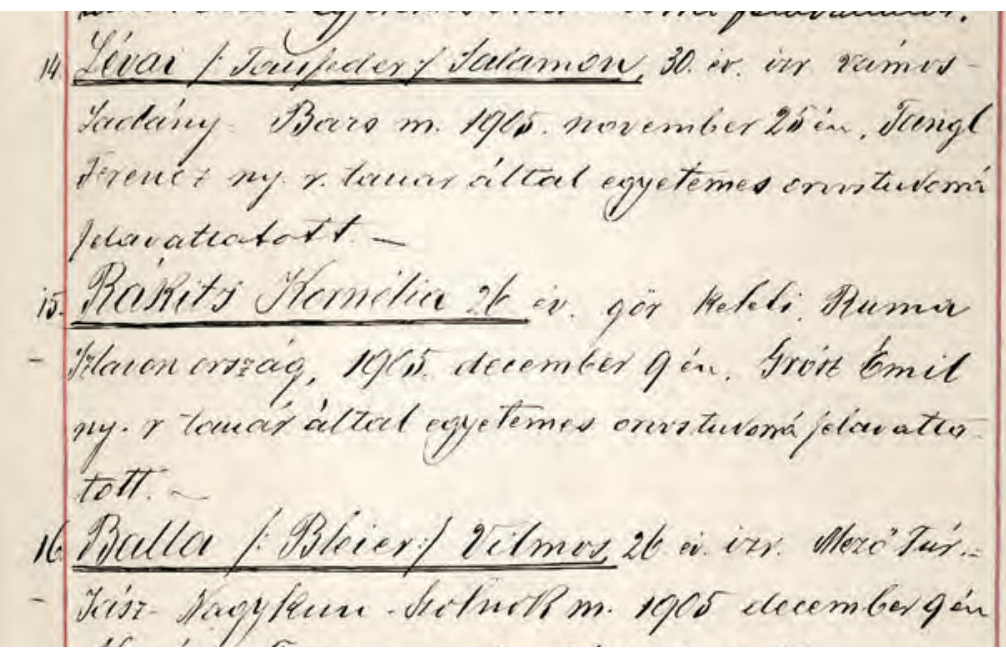

Picture 2. The page of the register of graduated students ("Golden Book") of the Medical Faculty in Budapest giving Kornelia Rakić's date of graduation. With permission of Archives of Semmelweis University, Budapest.

practice for women and children in the main street of the city (Pictures 4,5$)(3,24)$. The initiative to establish herself as a local "woman doctor for women" was doubtlessly welcomed and supported by the "women's club"; however, it was premature. Data concerning Rakić's practice as a doctor in Novi Sad are not available; ${ }^{6}$ however, it is likely that

${ }^{6}$ Kornelija Rakićs "Form of personal and official data” (a form of the Ministry of Public Health of the Federal Republic of a sufficient number of female private patients failed to materialize. Forced to look elsewhere for an opportunity to practice her profession, Kornelija Rakić learned that the $\mathrm{AH}$ administration of Bosnia and Herzegovina (BH) had not yet staffed all positions for official female doctors in the country.

Later in 1906, Kornelija Rakić travelled to Sarajevo to introduce herself personally to the AH public health authorities. It was probably helpful to her cause that the Bihać district administration sent a letter to the provincial public health authorities in Sarajevo urging the appointment of an official female doctor for the district in October 1906. This letter was sent in reference to an intervention of the local mufti Hadži Jusuf ef. Jahić ${ }^{7}$ and other Muslim notables in the matter and the high mortality of Muslim mothers and infants in the district $(23,25)$.

The evaluation process for Rakićs application as an "official female doctor with forensic medical function" (Amtsärztin mit gerichtsärz-

Yugoslavia that all physicians in Yugoslavia were required to complete after World War II) (24) does not contain information about her private practice in Novi Sad.

${ }^{7}$ Hafiz Yusuf-ef. Jahić (Zijauddin-ef), was born in Miljanovci Kalesija in 1853 and died in Tuzla, BH in 1928 (Bosnia and Herzegovina). He was the Mufti of Bihać for 26 years (18881914). He completed higher theological education as a cadet and state scholarship holder in Istanbul (Ottoman Empire). He was awarded the Golden Order of Merit of the AustroHungarian emperor Franz Joseph I. He advocated the introduction of modern education and health care for Muslim women (27). 


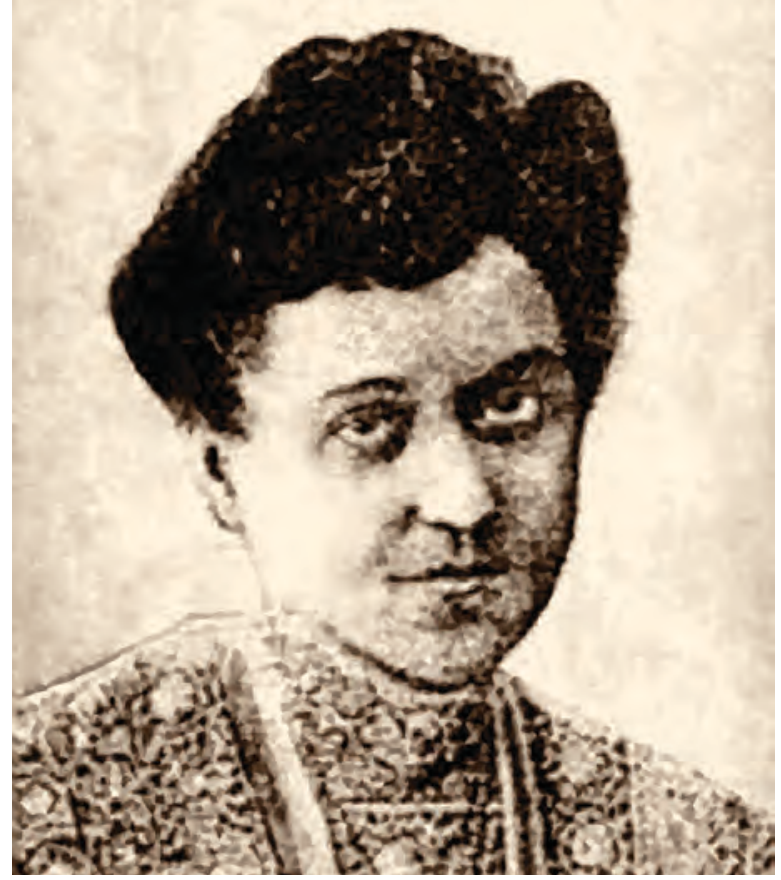

Picture 3. Kornelija Rakić, about 1910.

tlichen Funktionen) took more than a year, but the application was finally approved. In January 1908, the authorities decided to employ Kornelija Rakić as an official female doctor in Bihać (23). They explained their decision by pointing out that Kornelija Rakić was a native of the AHE who had acquired her MD at a domestic university and was

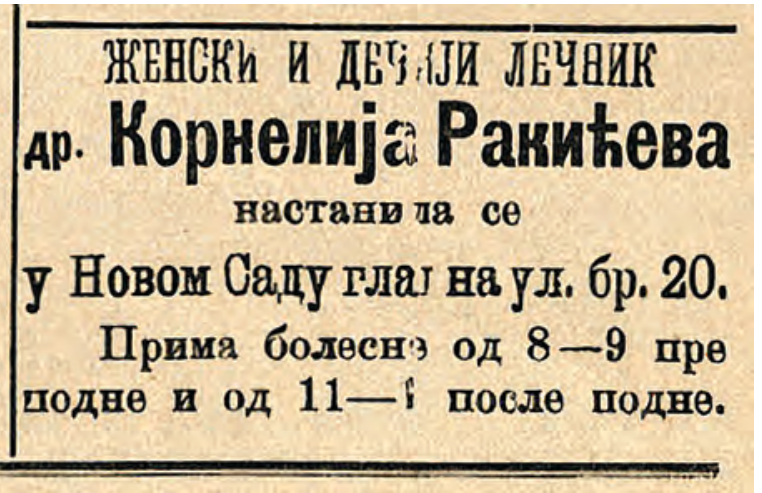

Picture 4. Advertisment for "Dr. Kornelija Rakić's" practice in Novi Sad, published in "Zastava", 1906 Feb 4; p. 4 (col. 4).

familiar with the native "custom and language". She was also younger than any other official female doctor and "evidently of good health", which was considered a great advantage (28). Kornelija Rakić received her decree of appointment as an official female doctor in Bihać, Bosnia on 11 April 1908 $(23,26)$. She closed her practice "for women and children" in Novi Sad and left for Bosnia.

In Bosnia, she worked in Bihać (1908-1912), Banja Luka (1912-1918) and Mostar (1918-1949) $(23,26)$. She retired in 1949 at the age of $70(29)$ and died on 11 July 1952 (30) in Mostar. Kornelija Rakić was buried at the Orthodox cemetery in "Bjelušine". The wooden cross with her name has since vanished and no tomb-

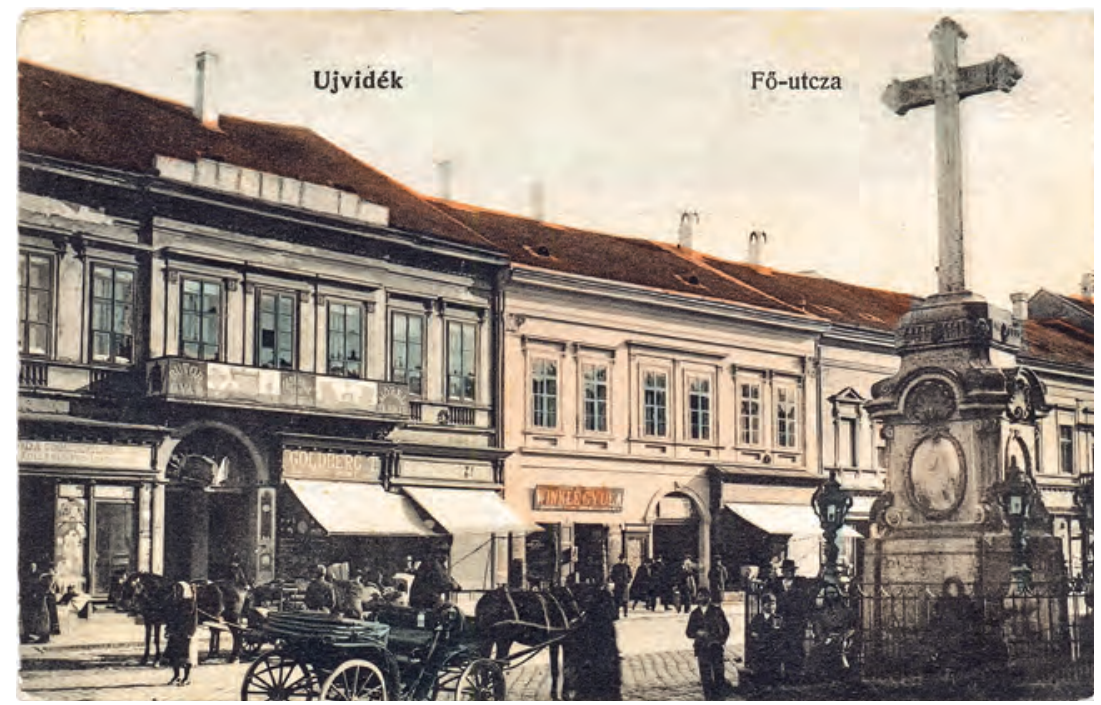
stone was placed on the spot; therefore, her grave is not easily identifiable, except by a palm tree sprouting at the site (Picture 6). Kornelija Rakić received numerous $\mathrm{AH}$ commendations and awards as an AH official female doctor in $\mathrm{BH}$. She was awarded the Order of St. Sava of the Third Degree twice: once by the Ministry of Health and once by the Ministry of Social Affairs of the Kingdom of Yugoslavia (31).

Picture 5. Novi Sad: The building (Light Pink) where Kornelija Rakic's private practice was located in 1906. 


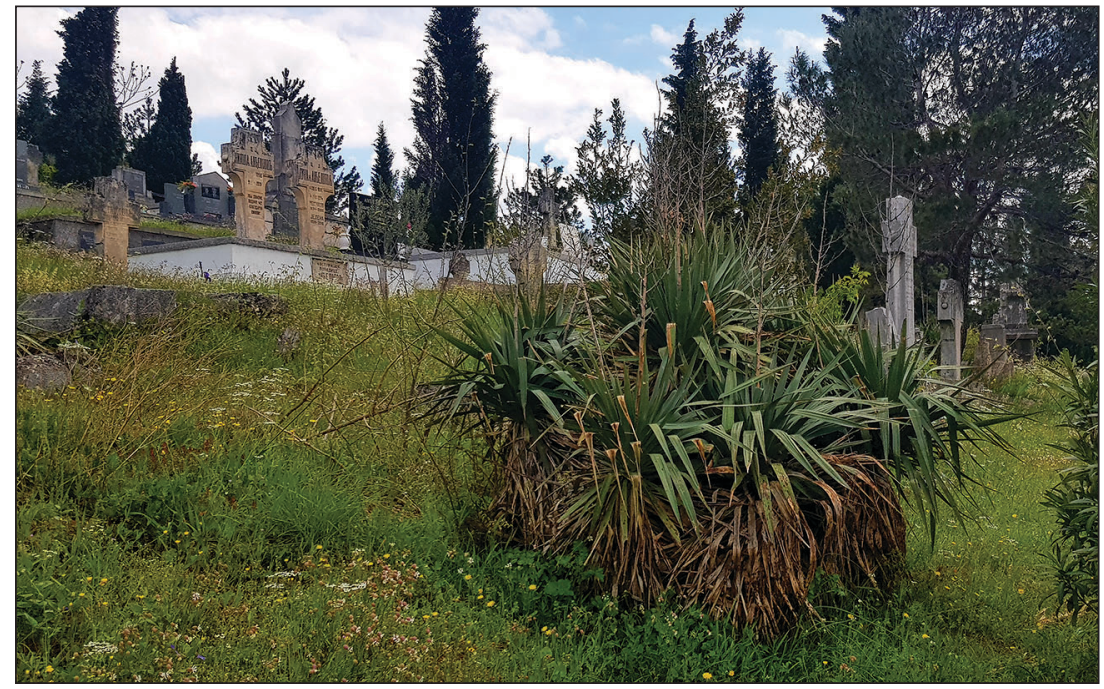

Picture 6. Kornelija Rakić's unmarked grave at the Bjelušine cemetery in Mostar, recognizable by the palm tree.

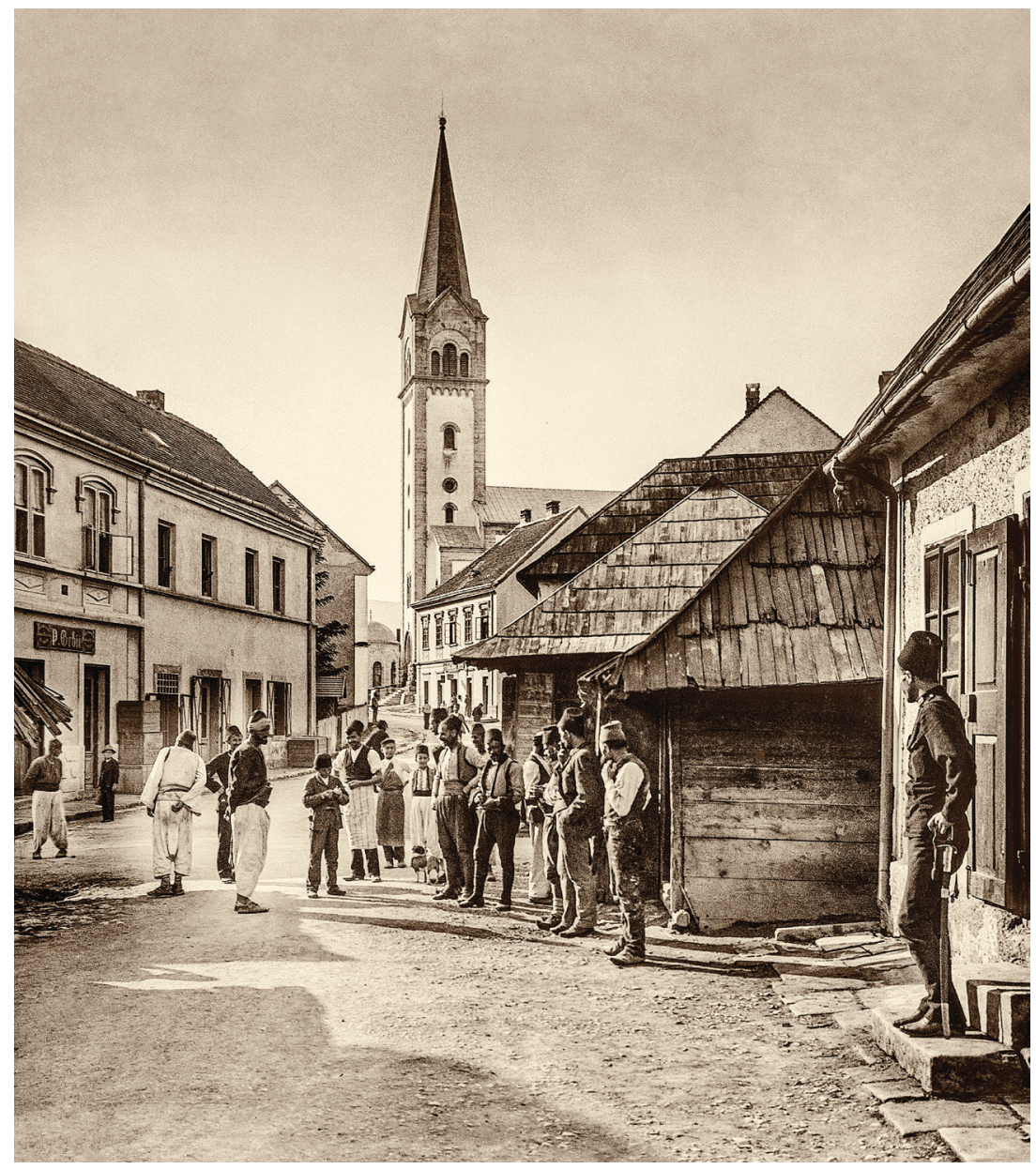

Picture 7. Bihać at the time when Kornelija Rakić started working there. Street scene with a view of the Roman Catholic Church [in German]. Signature: PCH 3.033 - C POR MAG. Available from: http://data.onb.ac.at/rec/baa13769435 and https://www.onb. ac.at/.

\section{Kornelija Rakić's}

Professional Activities in Bosnia and Herzegovina

The previously employed $\mathrm{AH}$ female health officers were sworn into their offices at their residences. However, Kornelija Rakić took her oath of office in Sarajevo on 4 May 1908. Due to "budgetary reasons", she did not report for duty in Bihać until 1 August 1908; at that time, she was assigned to the provincial hospital in Sarajevo, where she had completed an internship (26). Rakićs position as an official female doctor of Bihać became permanent on $4 \mathrm{Au}$ gust $1909(4,23)$.

Bihać (Picture 7), located in northeast Bosnia, was the smallest and least populated district of Bosnia at the time, and most of the rural population was Serbian. The district capital counted 6,201 inhabitants in 1910, of whom $61.0 \%$ were Muslim, 27.5\% were Roman Catholic and 8.5\% were Serbian-Orthodox (32). The AH administration had established a community hospital with 31 beds, which was rebuilt and enlarged in 1887/1888 (33).

Presumably, Kornelija Rakić ran an outpatient ward for women and children in accordance with the instructions for $\mathrm{AH}$ female health officers in $\mathrm{BH}$. However, there is no evidence of her practice for local women and children other than annual assessments 
by her superiors. These assessments attest that Rakić was an excellent doctor who was popular with her patients and often visited by Muslim women, as well as an excellent obstetrician (23). Rakić was not able to spend much time with her outpatients, according to an assessment written by her recently appointed superior, district doctor Martin Bleicher, in 1911. Bleicher praised her participation in syphilis eradication in the subdistricts of Cazin and Krupa and remarked that she had not had many other opportunities to pursue professional work (23). Kornelija Rakić was intensively involved in the eradication of syphilis campaign in the aforementioned subdistricts from the time she took office in 1908. In 1909, she was also commissioned as a substitute to manage the community hospital in Bihać (23).

In 1905-1906, the focus of AH public health policies in $\mathrm{BH}$ shifted from popularizing public health utilization to campaigning for syphilis eradication. Control of the widespread endemic of syphilis was considered a priority as early as the 1880s; however, the AH public health authorities had considered it unwise to carry out an unpopular military-led syphilis eradication campaign in $\mathrm{BH}$. After the turn of the century, the authorities concluded that the whole population of $\mathrm{BH}$ must be subject to thorough medical examinations $(34,35)$. All female doctors in the country, including private

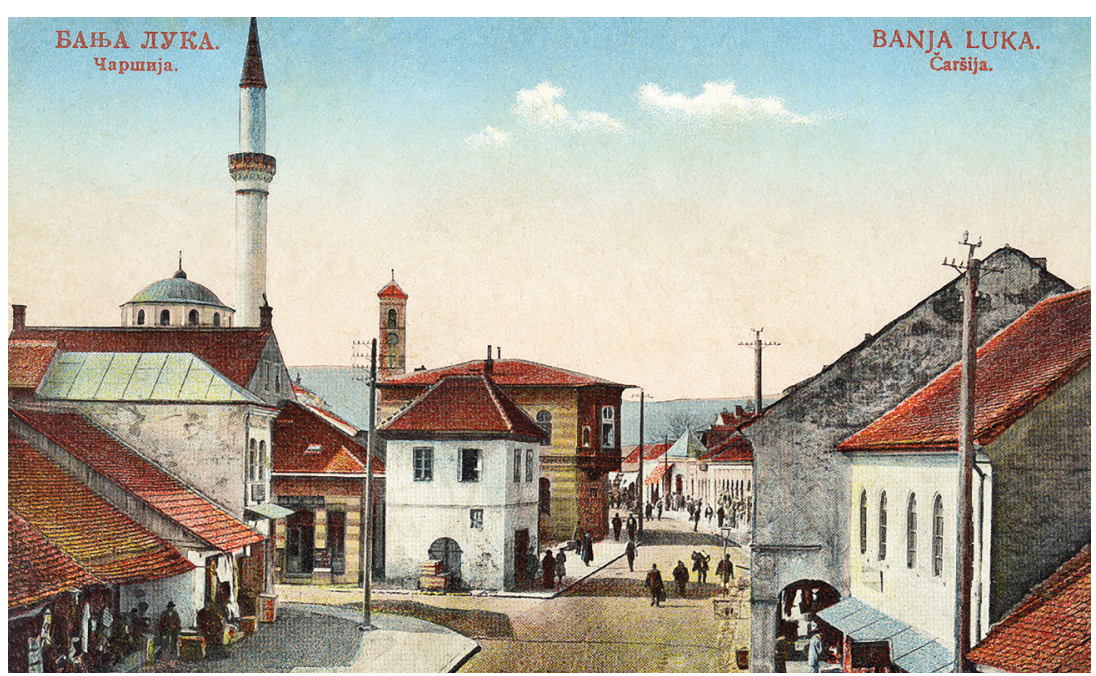

Picture 8. Banja Luka at the time when Kornelija Rakić started working there. Published with kind permission of Museum of the Republika Srpska, Banja Luka, Bosnia and Herzegovina. doctors Gisela Januszewska and Rosa EinhornBloch, were ordered to examine the female Muslim population for symptoms of (endemic) syphilis. Evidently, the $\mathrm{AH}$ official female doctors considered syphilis eradication a great burden (36). Two petitions for equal pay in 1908 and 1912 were signed by all AH official female doctors. Among other things, these petitions argued that $\mathrm{AH}$ official female doctors could no longer treat private patients because they had to spend 100-200 days per year working on syphilis eradication (25). Due to these constraints, the doctors were also prevented from spending time on their outpatient practices. The burden of anti-syphilis campaigning contributed to the decision of private doctors Gisela Januszewsa (Banja Luka) and Rosa Einhorn-Bloch (Travnik) to leave the country.

By 1912, Kornelija Rakić was one of only three female doctors remaining in $\mathrm{BH}$. She applied successfully for a transfer to Banja Luka (Picture 8)then a city of about 25,000 inhabitants-after her superior had assessed her "behaviour towards colleagues in Bihać" as "uncooperative" (23).

In Banja Luka, Rakić took over from Gisela Januszewska in October 1912. Her superior in Banja Luka explicitly rejected his predecessor's criticism, attesting in 1913 that Kornelija Rakić had "won the affection of the entire population by her modest, amiable and philanthropic behaviours" (23). In addition to her work as a general practitioner for women and children, she was commissioned (like her predecessor) to provide hygiene lessons at a higher girls' school in Banja Luka $(37,25)$. AH sources indicate that Kornelija Rakić was also intensively involved in anti-syphilis campaigning (25) and she was commissioned repeatedly to work at the "district hospital" (Bezirksspital) of Kotor Varoš. The district hospital had about 30 beds and, like all established "district 


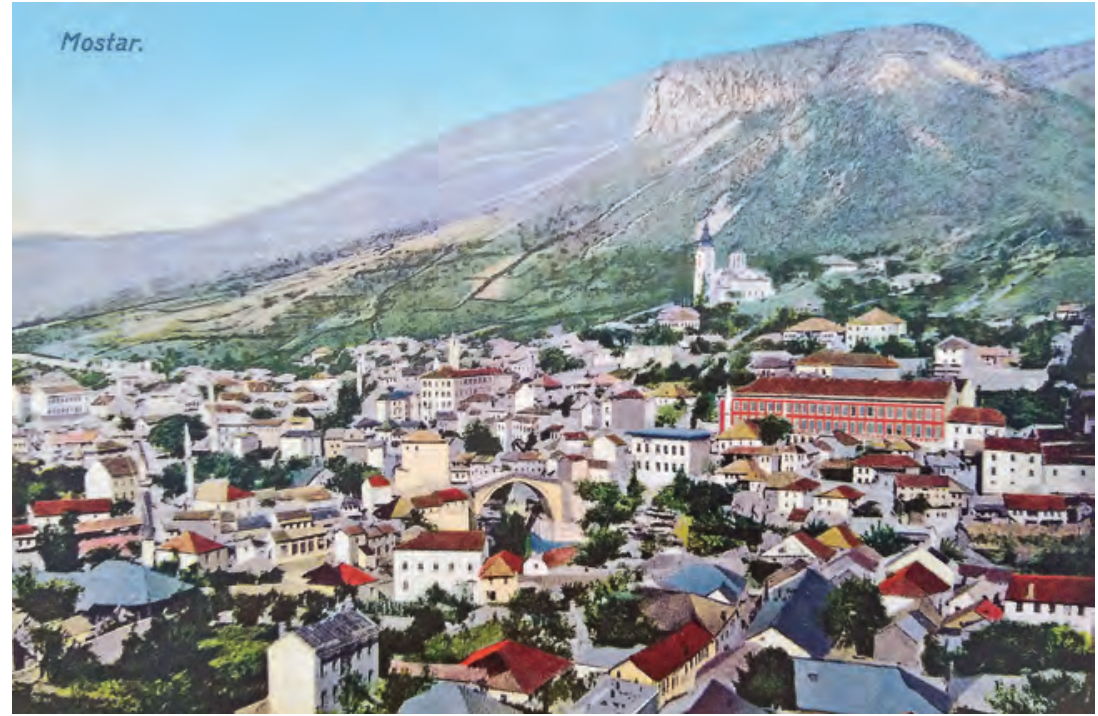

Picture 9. Mostar at the time when Kornelija Rakić started working there. With Permission from Mr. Zlatko Serdarević of Mostar.

hospitals", it was primarily dedicated to syphilis treatment (38). During the 1915 cholera epidemic in Bosnia, Kornelija Rakić was tasked with combating cholera in the districts of Banja Luka and Travnik. During World War I, she received AH awards for her commitment to combating syphilis and cholera (26).

In December 1917, Kornelija Rakić was informed that she would be transferred to Mostar in the summer of 1918. The position of official female doctor of Mostar had become vacant after the death of Bohuslava Kecková in 1911. Keckovás death likely delayed the syphilis eradication campaign in Herzegovina. On her way to Mostar in late June 1918, Rakićs health declined, and she spent several months on sick leave in Sarajevo. She finally arrived in Mostar (Picture 9) days before the monarchy collapsed in October 1918 and $\mathrm{BH}$ became a part of the newly established Kingdom of Serbs, Croats and Slovenes.

Kornelija Rakić decided to stay in Mostar and took her oath of allegiance to King Peter in February 1919 (Picture 10) and King Alexander in September 1921 (23). From 1918-1926, she continued her function as a public health officer of the "Mostar region", and worked later, until her retire-

${ }^{8}$ After World War I, Mostar had become the administrative ment in 1949, as the head of the "Dispensary for Mothers and Children" at the Public Health Centre in Mostar.

The new state faced problems including starvation, significant child mortality, prevalent war epidemics and spread of endemic diseases such as syphilis, malaria and trachoma in Herzegovina; therefore, the public health system relied on the development of socio-medical institutions. In Mostar, a "bacteriological ward" (Stalna bakteriološka stanica) opened in 1923 and served as a foundation for the "public health centre" founded in 1929 (39). The latter included gradually established "dispensaries" to serve patients suffering from malaria, skin and venereal diseases and tuberculosis, as well as a children's dispensary and "school policlinic" founded in 1926 and headed by the Bosnian paediatrician Berta Bergman. ${ }^{9}$ In 1929, a "Dispensary for mothers and children" (Dispanzer za majke i djecu) was established (40) under the direction of Kornelija Rakić. She had attended the Institute for Health Care for Moth-

center of "Mostarka oblast" (Mostar region). As a result of the reorganization of the Yugoslavian state in 1929, Mostar region became part of the 1929-1939 existing province ("banate") Primorska banovina (Littoral Banovina), cf. Political Representation of $\mathrm{BiH}$ in the Kingdom of Serbs, Croats, and Slovenes / Kingdom of Yugoslavia (1918-1941) [in Bosnian]. [cited 2020 Feb 9] Available from: https://www.parlament.ba/ Content/Read/180?title=Politi\%C4\%8DkopredstavljanjeBiH uKraljeviniSrba, HrvataiSlovenaca/KraljeviniJugoslaviji(191 8.\%E2\%80\%931941.

${ }^{9}$ Berta Bergman (1892-1945) was the first Bosnian woman who had qualified for university education and studied medicine in Vienna. When the Dispensary for Mothers and Children (Dispanzer za majke i djecu) was established in 1929, Kornelija Rakić was appointed as its chief. Berta Bergman became at that point the head of the newly established "School Polyclinic" (Školska poliklinika). Berta Bergman was arrested on January 14,1945 , and deported to the Jasenovac concentration camp, where she was murdered [cited 2021 Apr 8]. Available from: https://en.wikipedia.org/wiki/Berta_Bergman. 
ers, Children, and Youth in Sarajevo and studied "social paediatrics and child health" with two other pioneers of Yugoslavian social medicine and hygiene, Maša Živanović ${ }^{10}$ and Mara Kurtović. ${ }^{11}$

Rakić treated 907 pregnant women, 2,225 infants, and 10,429 children at the Mostar "Dispanzer za majke i djecu" in 1929; her patients were 63\% Muslim, 20\% Orthodox and 17\% Catholic. As head and manager, Kornelija Rakić also organized and coordinated activities to educate the local women about public health and hygiene, and she was a lecturer as well (10). She also gave hygiene lessons at a higher school in Mostar (46). Kornelija Rakićs practice for women and children at the Mostar Public Health Centre was not interrupted when $\mathrm{BH}$ was annexed by the pro-NS NDHstate in 1941 (7). Rakić supported the local anti-fascist resistance against the pro-NS "Independent States of Croatia" (26) and the premises of the children's policlinic and the maternity and child welfare ward in Mostar provided refuge to wounded partisans, sick members of the resistance and displaced persons (10).

After World War II, the social and health situation in Herzegovina was precarious, and the public health care system in Mostar needed to be reorganized. Kornelija Rakić was

\footnotetext{
${ }^{10}$ Maša Živanović (1898-1960) was a reputed pediatrician in Sarajevo in the interwar years. She was the head of the Children's Dispensary and the Institute for Health Care for Mothers, Children, and Youth in Skerlićs Street in Sarajevo. After World War II, she performed the same duty. Živanović was a well-known women's activist and president of the Women's Movement in Sarajevo (1924-1936).

${ }^{11}$ Mara Kurtović (1892- ?) was the first expert of school hygiene in Bosnia and Herzegovina. She was the head of the Children's Dispensary at the Institute for Health Care for Mothers, Children, and Youth in Skerlićs Street in Sarajevo.
}

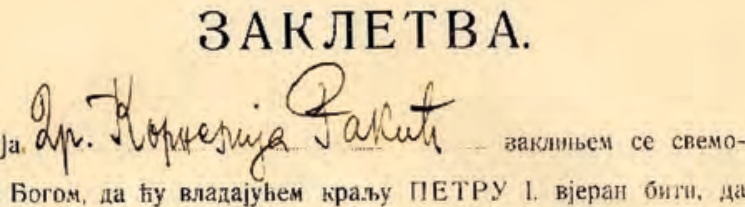

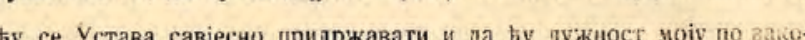
нима $n$ законским наредбама предиостављених ми власти тачио и савјесно отправљати.
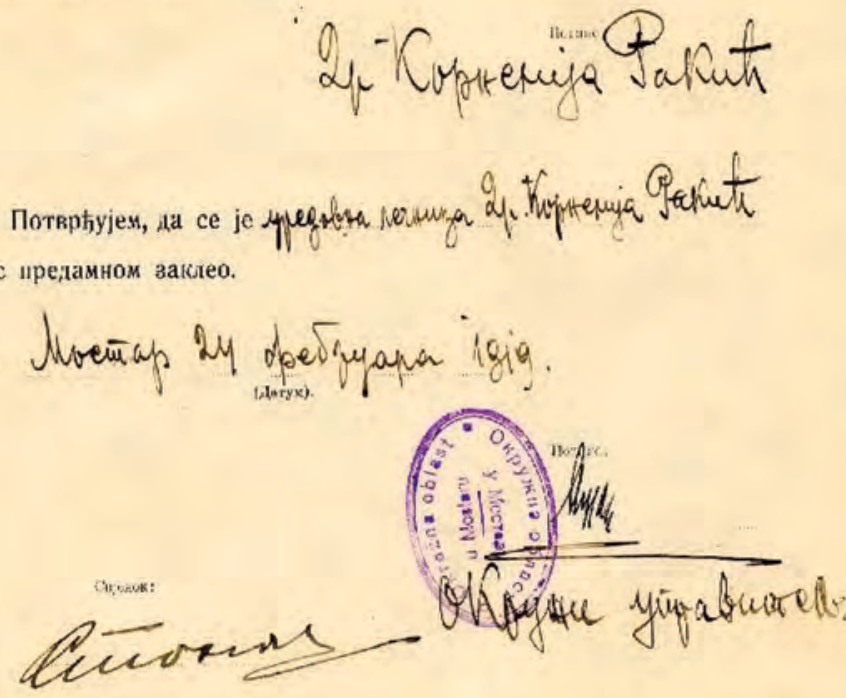

11. aut. 2e: 1418.19 .

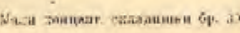

Picture 10. Kornelija Rakić's Oath of allegiance to King Petar/Peter I. stating that she will abide by the constitution and exercise her duty according to the laws and regulations. Archives of Bosnia and Herzegovina.

employed by the public health department of the People's Committee for Herzegovina as head of a new children's and maternity dispensary $(42,43)$ comprised of three medical departments, a pharmacy and a kitchen that provided free meals to malnourished local children. However, she was the only doctor at the clinic, along with a dentist, two health care professionals and four auxiliary technical workers. According to Rakić's report, the maternity department was consulted by 514 pregnant women in March 1946, 136 of whom were gyne- 
cologically examined. A total of 494 children were examined in the department for mothers, infants, and young children, and 648 children were served in the "children's dispensary". The pharmacy issued prescribed medications, ointments, vitamin preparations (e.g., cod liver oil) and medical devices for children's treatment at home. The kitchen distributed 2,169 servings of cocoa and 2,333 servings of bread to 100 undernourished children, and each child had gained between 250-500 grams of body weight during the month (44).

After 1945, Kornelija Rakić served as vice president of the Red Cross Society in Mostar (30) and distributed relief supplies such as food and cod liver oil to local children and pregnant women. Despite her advanced age, she continued to practice as a doctor for women and children, and she never tired of drawing the authorities' attention to the social and medical welfare of the "new generations" (44). She was a pioneer of social medicine who dedicated her life to the welfare of women, mothers and children.

\section{Concluding Remarks}

Kornelija Rakić was the first female doctor in Novi Sad as a city that was located at Hungary's periphery but was a center of Serbian national culture and politics. Born as a Hungarian citizen in Ruma, Syrmia in 1879, Kornelija Rakić belonged to the first generation of female doctors in the AHE who were able to acquire their MDs at domestic universities. Following the completion of her medical studies in Budapest and a futile attempt to establish herself as a "woman doctor for women and children" in Novi Sad, she began her career as an AH official female doctor in occupied, then annexed, Bosnia in 1908. Kornelija Rakić was eventually transferred to Mostar, where she worked for over thirty years, first as an official doctor in the service of the AH (1918) and later as a district public health officer (1918-1926) in the service of the Kingdom of Serbs, Croats and Slovenes. A pioneer of social medicine, she became the head of the maternity and child welfare ward of the Mostar Public Health Centre, founded in 1929, where she practiced until her retirement in 1949. Kornelija Rakić died in Mostar in 1952, having dedicated her life to the welfare of women and children.

Authors' Contributions: Conception and design: HT and BF; Acquisition, analysis and interpretation of data: $\mathrm{HT}$ and BF; Drafting the article: HT and BF; Revising it critically for important intellectual content: HT and BF; Approved final version of the manuscript: $\mathrm{HT}$ and BF.

Conflict of Interest: The authors declare that they have no conflict of interest.

\section{References}

1. Tomić M. Dr. Kornelija Rakić [in Serbian]. Žena. 1911;1(1):2.

2. Kolarić A. Gender, nation, and education in the women's magazine Žena (The woman) (1911-1914). Espacio, Tiempo y Educación. 2017;4(1):1-23. doi: http://dx.doi. org/10.14516/ete.142

3. Stojaković G. Dr. Kornelija Rakić. In: Stojaković G, editor. Famous women of Novi Sad [in Serbian]. Novi Sad: Futura publikacije; 2001. p. 176-177.

4. Nečas C. Among Muslim Women. The activities of the female health officers in Bosnia and Herzegovina, 18921918 [in Czech]. Brno: Masaryk University; 1992.

5. Jeremić R. Contributions to the biographical dictionary of the Serbian physician of Vojvodina 1756-1940 [in Serbian]. Novi Sad; 1952. p. 119.

6. Berić BM, Sloboda L, Subotić J. The first women physicians in Vojvodina (1893-1919) [in Serbian]. Med Pregl. 1988;41(1-2):79-82.

7. Mulić S. Health conditions in Herzegovina during the Second World War with special attention to the area of Konjic [in Bosnian]. In: Kamberović H, editor. Bosna i Hercegovina 1941: Novi pogledi. Sarajevo: Institut za istoriju; 2015. p. 115-142.

8. Tolj Z. Half a century at the scene of the fight for national health [in Croatian-Serbian]. In: Tolj Z, editor. 50th anniversary of the Regional Institute for Health Care Mostar [in Croatian-Serbian]. Mostar: Regionalni zavod za zdravstvenu zaštitu Mostar; 1980. p. 11-54.

9. Šimić Lj. Memories. [in Croatian-Serbian]. In: Tolj Z, editor. 50th anniversary of the Regional Institute for Health Care Mostar [in Croatian-Serbian]. Mostar: Regionalni zavod za zdravstvenu zaštitu Mostar; 1980. p. 358-364.

10. Žurovec M. The development of the health care of mother and child. [in Croatian-Serbian]. In: Tolj Z, editor. 50th anniversary of the Regional Institute for Health Care Mostar [in Croatian-Serbian]. Mostar: Regionalni zavod za zdravstvenu zaštitu Mostar; 1980. p. 221-228. 
11. Kornelija Rakićs certificate of birth from Ruma [in Serbian]. Registry office of the city of Ruma, Serbia. No. 20000-2020; December 25, 2020.

12. Historical Archive "Srem" Sremska Mitrovica. Testimony of persons from the 'first composition' who lost their right to vote, based on the Electoral Order Act 1881 and the Order of the High Royal Government of the Department of the Interior of 1882 [in Serbian]. Fund - Ruma Market Magistrate, box 6.401-9.271.

13. Bošković Đ. Ruma in the period 1861 - 1914 [in Serbian]. Ruma: Zavičajni Muzej Ruma; 2016. p. 373; 392.

14. Stojaković G. "Women's World" (1886-1914). Serbian women's laboratory as an entrance into the public sphere. Journal of the North American Society of Serbian Studies. 2011;25(1):21-57.

15. Spasović I. Higher Schools for girls in Serbian language in the region of Banat Military Border in the period of Hungarian rule. Research in Pedagogy. 2013:3(2):61-70.

16. Women's World - Journal of Charitable Cooperative of Serbian Women in Novi Sad [in Serbian]. 1981;6(3):43.

17. Letter from Kornelija Rakić sent to Arkadije Varađanin in 1901 [in Serbian]. Matica Srpska Novi Sad; Manuscript Department. Inventory number: 15612.

18. Anonymous. Editors and Collaborators [in Serbian]. Daily newspaper Zastava in Novi Sad. 1926 Feb 23; p. 4 (col. 3).

19. Historical Archives of the City of Novi Sad, F 25 Gymnasium “Jovan Jovanović Zmaj”, book 75; Register of students of I-VIII grades 1896/1897 and 1897/1898; book 76 - Register of students of I-VIII grades 1898/1899 and 1899/1900 [in Serbian].

20. Maturity exam, Kornelija Rakić, Historical Archives of the City of Novi Sad, Gymnasium "Jovan Jovanović Zmaj: The main protocol of exams maturity 1897-1905, No. 37 [in Serbian].

21. Müller I. The social composition of the female student body of the University of Budapest (1896-1914) / The social composition of female students at the Budapest University of Sciences (1896-1914) [in Hungarian]. Korall Társadalomtörténeti folyóirat. 2001;(3-4):203-20.

22. Note in the so-called "Gold book" of the graduated students at the Medical Faculty of Budapest. Budapest: Archives of Semmelweis University; 1905. p. 417.

23. Archives of Bosnia and Herzegovina. Service and qualification table of Dr. Kornelija Rakić [in German]. Collections of personal files of the Archives of Bosnia and Herzegovina. Box No. 436.

24. Advertisement: Female and pediatric physician Dr. Kornelija Rakić. Daily newspaper Zastava, Novi Sad; 1906 Feb 4; p. 4 (col. 4).

25. Martin B. About the work of Kornelija Rakić as a medical officer in Bosnia Herzegovina [in German] [cited 2002 Jul 9]. Available from: https://www.scribd.com/ document/360574359/Zur-Tatigkeit-von-KornelijaRaki\%C4\%87-als-Amtsarztin-in-Bosnien-Herzegowina.
26. Form of personal and official data of Dr. Kornelija Rakić [in Serbian]. Archives of Yugoslavia, fund 39, fasc. 5, dated March 6, 1922.

27. Mešić M. Bihać madrasa [in Bosnian]. Bihać: NIP "Unsko-sanske novine"; 1998. p. 80.

28. Provincial Government for Bosnia and Herzegovina Sarajevo doc. No. 149, 745 [in German]. Arhiv Bosne i Hercegovine: 1907, box No. 51, code 38-43.

29. Anonymous. Biographies [in Croatian-Serbian]. In: Tolj $Z$, editor. 50th anniversary of the Regional Institute for Health Care Mostar [in Croatian-Serbian]. Mostar: Regionalni zavod za zdravstvenu zaštitu Mostar; 1980. p. 383.

30. Kornelija Rakić certificate of death from Mostar [in Bosnian]. Registry office of the city of Mostar. No. 09-101264/2021; April 12, 2021.

31. The Order of St. Sava [in Serbian]. Glasnik lekarske komore za Bosnu, Hercegovinu, Dalmaciju i Crnu Goru. 1927;3(4):40.

32. Landesregierung für Bosnien und die Hercegovina, editor. Results of the Census from October 10, 1910 in Bosnia and Hercegovina [in German]. Sarajevo: Landesdruckerei; 1912. p. XXIII, Tafel 11; p. 226-227.

33. Landesregierung für Bosnien und die Hercegovina, editor. Public Health in Bosnia and Herzegovina 1878-1901 [in German]. Sarajevo: Landesdruckerei; 1903.

34. Syphilis eradication campaign in Bosnia and Herzegovina [in German]. Int Klin Rd. 1912;(33):519.

35. Syphilis eradication campaign in Bosnia and Herzegovina [in German]. Int Klin Rd. 1912;(34):535.

36. Krajewska z Kosmowskich T. Diary (prepared for print by Boguslawa Czajecka) [in Polish]. Cracow: Krajowa Agencja Wydawnicza; 1989. p. 136-7; 162-8.

37. Sixteenth annual report of the State Girls' High School in Banja Luka [in Bosnian]. Banjaluka: Tiskara Fon i Grgić (J. S. Wolf); 1914. p. 28.

38. Landesregierung für Bosnien und die Hercegovina (ed). Public Health in Bosnia and Herzegovina 1878-1901 [in German]. Sarajevo: Landesdruckerei; 1903. p. 324.

39. Komadina M. Construction and adaptation of the Institute [in Croatian-Serbian]. In: Tolj Z, editor. 50th anniversary of the Regional Institute for Health Care Mostar [in Croatian-Serbian]. Mostar: Regionalni zavod za zdravstvenu zaštitu Mostar; 1980. p. 287-292.

40. Babić L, Harambašić K, Ravlić S. Development of health organizations in Mostar and Herzegovina [in CroatianSerbian]. In: Tolj Z, editor. 50th anniversary of the Regional Institute for Health Care Mostar [in CroatianSerbian]. Mostar: Regionalni zavod za zdravstvenu zaštitu Mostar; 1980. p. 74-83.

41. Miletić KD. Great Gymnasium in Mostar [in Croatian]. Mostar: Crkva na kamenu; 2003. 
42. List of staff of the Health department of the District people's committee for Herzegovina December 4, 1945. HONO Mostar 1945: Department of Health No. 1-6000 HNK Archives [in Croatian-Serbian].

43. Mulić J. The health care in Konjic from ancient time until today [in Bosnian]. Konjic: Opšta Bolnica Konjic; 2010. p. 204-205.
44. Monthly Activities Report of Maternity and child welfare dispensary Mostar for March 1946 sent to District people's committee for Herzegovina - Department of Public Health. HONO Mostar 1945: Department of Health No. 142-4884, HNK Archives [in Croatian-Serbian]. 